\title{
Partial Purification and Characterization of Glutamate Synthase from a Thermophilic Bacillus
}

\author{
By C. N. G. SCHMIDT† AND L. JERVIS* \\ Department of Biology, Paisley College of Technology, High Street, Paisley PA1 2BE, U.K.
}

(Received 30 October 1981)

Glutamate synthase (GOGAT), glutamine synthetase (GS), $\mathrm{NAD}^{+}$-dependent glutamate dehydrogenase $(\mathrm{GDH})$ and $\mathrm{NAD}^{+}$-dependent alanine dehydrogenase $(\mathrm{AlaDH})$ activities were detected in cell extracts of Bacillus stearothermophilus $\mathrm{PH} 24$, a strain deficient in $\mathrm{NADP}^{+}$-dependent GDH. GDH and GOGAT activities were low under most growth conditions and GOGAT was not detectable in extracts of cells grown with amino acids as carbon and nitrogen source. AlaDH and GS activities were more variable, the former being high in cells grown on L-alanine as carbon and nitrogen source. GS was repressed during growth with high concentrations of $\mathrm{NH}_{4} \mathrm{Cl}$ as nitrogen source but a corresponding increase in $\mathrm{AlaDH}$ activities suggests that this enzyme may replace $\mathrm{NADP}^{+}$-dependent $\mathrm{GDH}$ as the main enzyme for ammonia assimilation under these conditions.

GOGAT was purified 40-fold using affinity chromatography on NADPH-Sepharose. The molecular weight of the partially purified enzyme was estimated to be 160000 and $K_{\mathrm{m}}$ values for NADPH, 2-oxoglutarate and L-glutamine were 22,15 and $29 \mu \mathrm{M}$, respectively. Glutamine could be replaced by $\mathrm{NH}_{4} \mathrm{Cl}$ as nitrogen donor $\left(K_{\mathrm{m}} 44 \mathrm{mM}\right)$ but the rate was only $10 \%$ to $15 \%$ that of the L-glutamine-dependent reaction. The $\mathrm{pH}$ optimum for glutamine-dependent activity was 8.0 and the temperature optimum $75^{\circ} \mathrm{C}$ : the enzyme displayed a discontinuous Arrhenius plot over the range $30^{\circ} \mathrm{C}$ to $75^{\circ} \mathrm{C}$. Azaserine, L-methionine sulphone and Cibacron Blue 3GA were all inhibitors and the enzyme was rapidly inactivated in the presence of NADPH when L-glutamine and 2-oxoglutarate were absent.

\section{IN T RODUCTION}

Initially, many bacteria were thought to produce glutamate using the enzyme glutamate dehydrogenase (GDH; NADP ${ }^{+}$-dependent; EC 1.4.1.4) and, in bacilli lacking this enzyme, by production of alanine dehydrogenase $(\mathrm{AlaDH}$; EC 1.4.1.1) and subsequent transamination (Hong et al., 1959). Recent work, however, showed that, during growth with low concentrations of ammonia, glutamate is produced by the combined action of glutamine synthetase (GS; EC 6.3.1.2) and glutamate synthase (GOGAT; EC 1.4.1.13) (Tempest et al., 1970; Nagatani et al., 1971; Tempest et al., 1973). This pathway operates in several bacilli (Elmerich \& Aubert, 1971; Hemmilä \& Mäntsälä, 1978; Deshpande \& Kane, 1980) and GOGAT has been purified from the mesophilic organisms Bacillus megaterium (Hemmilä \& Mäntsälä, 1978) and Bacillus subtilis (Deshpande \& Kane, 1980).

No study of GOGAT from a thermophilic source has been made, although other ammonia assimilation enzymes have been studied (Wedler \& Hoffman, 1974; Epstein \& Grossowicz, 1975, 1976). For this reason a study was undertaken on Bacillus stearothermophilus $\mathrm{PH} 24$ to demonstrate the presence of GOGAT and its function in glutamate formation, and subsequently, to purify and examine the properties of this enzyme.

† Present address: Department of Botany, Rothamsted Experimental Station, Harpenden, Hertfordshire AL5 2JQ, U.K. 


\section{METHODS}

Materials. Sephadex G-25, Sephacryl S-300, Sepharose 6B and 2',5'-ADP-Sepharose were from Pharmacia, 2',5'-ADP and L-methionine sulphone were from Sigma and Cibacron Blue 3GA was from CIBA-Geigy.

Bacillus stearothermophilus strain PH24 was a gift from Dr J. A. Buswell of this department.

Bacterial growth. Bacillus stearothermophilus PH24 (Buswell \& Twomey, 1975) was grown in a medium containing $\left(\mathrm{g} \mathrm{l}^{-1}\right): \mathrm{KH}_{2} \mathrm{PO}_{4}(0.1), \mathrm{K}_{2} \mathrm{HPO}_{4}(0.4), \mathrm{MgSO}_{4} .7 \mathrm{H}_{2} \mathrm{O}(0.02)$, yeast extract $(0.05)$, and $1 \mathrm{ml}$ trace elements solution (Barnett \& Ingram, 1955) per litre; this medium was supplemented with carbon and nitrogen sources (see text). The organisms were grown in 21 baffled Erlenmeyer flasks containing 11 medium. The flasks were incubated at $55^{\circ} \mathrm{C}$ in an orbital incubator shaker (Gallenkamp) operated at $100 \mathrm{rev} . \mathrm{min}^{-1}$. Cells were collected using a continuous-flow centrifuge (Alfa-Laval Co., Brentford, Middlesex, U.K.) and the slurry from this was cleared by further centrifugation at $15000 \mathrm{~g}$ for $15 \mathrm{~min}$ in an MSE High Speed 18. Collected cells were washed with buffer $\left(25 \mathrm{mM}-\mathrm{KH}_{2} \mathrm{PO}_{4} / \mathrm{K}_{2} \mathrm{HPO}_{4} \mathrm{pH} 6.0\right.$ containing $1 \mathrm{mM}$-EDTA and $5 \mathrm{mM}$-2-mercaptoethanol) and stored frozen at $-20^{\circ} \mathrm{C}$ until required.

Preparation of cell extracts. Bacteria were thawed and suspended in the same buffer as used for washing $\left(3 \mathrm{ml} \mathrm{g}^{-1}\right)$. The suspension was cooled to $2^{\circ} \mathrm{C}$, sonicated and cell debris was removed from the extract by centrifugation at $30000 \mathrm{~g}$ for $1 \mathrm{~h}$ at $4^{\circ} \mathrm{C}$.

Enzyme assays. All assays were carried out at $55^{\circ} \mathrm{C}$ using a CE505 spectrophotometer (Cecil Instruments, Cambridge, U.K.) to measure the rate of dinucleotide oxidation at $340 \mathrm{~nm}$. The reaction mixtures (volume $3 \mathrm{ml}$ ) were as follows. GOGAT: $50 \mathrm{~mm}-\mathrm{K}^{+} / \mathrm{HEPES} \mathrm{pH} 8 \cdot 0,0.1 \mathrm{~mm}$-EDTA, $0.5 \mathrm{~mm}$-2-oxuglutrate, $1 \mathrm{~mm}$-L-glutamine

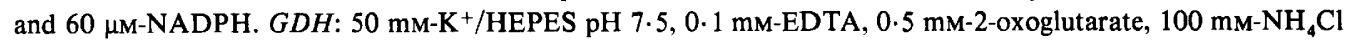

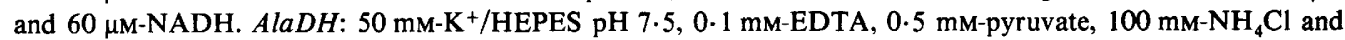
$60 \mu \mathrm{M}-\mathrm{NADH}$. The rate of dinucleotide oxidation in the absence of glutamine or $\mathrm{NH}_{4} \mathrm{Cl}$ was subtracted from the observed activities to allow for NADPH or NADH oxidase activity in the extract. $G S$ was assayed at $55^{\circ} \mathrm{C}$ using the transferase system of Wedler \& Hoffman (1974).

Enzyme activities. Enzyme activities are referred to as $\mu \mathrm{mol}$ dinucleotide oxidized $\mathrm{min}^{-1}$ (mg protein) ${ }^{-1}$ for dinucleotide-dependent enzymes and $\mu \mathrm{mol} \gamma$-glutamyl hydroxamate formed $(5 \mathrm{~min})^{-1}$ (mg protein) ${ }^{-1}$ for the GS forward transferase reaction.

Protein determination. Protein was determined by the Lowry method using bovine serum albumin as the standard.

Affinity adsorbent synthesis. NADPH was immobilized on Sepharose 6B via the nicotinamide ribose by the following procedure. NADP ${ }^{+}(200 \mu \mathrm{mol})$ and sodium periodate $(200 \mu \mathrm{mol})$ were each dissolved in $10 \mathrm{ml}$ water and incubated at $5{ }^{\circ} \mathrm{C}$ for $1 \mathrm{~h}$. Hexane diamine $(8 \mathrm{mmol})$ was dissolved in $20 \mathrm{ml}$ water and the $\mathrm{pH}$ of the solution was adjusted to $9 \cdot 5$ with $\mathrm{HCl}$ and then to $5 \cdot 5$ with $1 \mathrm{M}$-sodium acetate buffer, $\mathrm{pH} 5 \cdot 0$.

Periodate-oxidized NADP ${ }^{+}$was added and the mixture was stirred at $20^{\circ} \mathrm{C}$ for $2 \mathrm{~h}$ until Schiff's base formation occurred (indicated by the production of a deep yellowish-brown colour in the solution). The Schiff's base linkage between dinucleotide and diamine was reduced by adjusting the $\mathrm{pH}$ of the solution to 7.0 with $2 \mathrm{M}-\mathrm{NaOH}$ and adding $10 \mathrm{mg} \mathrm{NaBH}$ over a period of $5 \mathrm{~min}$. During this period the $\mathrm{pH}$ was maintained at $7.0 \mathrm{using} 1 \mathrm{M}-\mathrm{HCl}$.

The solution (now pale yellow) was adjusted to $\mathrm{pH} 10.0$ with $\mathrm{NaOH}$, diluted to $500 \mathrm{ml}$ with distilled water and applied to a $5 \times 15 \mathrm{~cm}$ column of DEAE-cellulose (DE-32) pre-washed with $\left(\mathrm{NH}_{4}\right)_{2} \mathrm{CO}_{3} / \mathrm{NH}_{4} \mathrm{HCO}_{3}$ buffer $(2 \mathrm{M}$, $\mathrm{pH} \mathrm{9.0)} \mathrm{and} \mathrm{then} \mathrm{water.} \mathrm{Following} \mathrm{application} \mathrm{of} \mathrm{the} \mathrm{reaction} \mathrm{mixture,} \mathrm{the} \mathrm{column} \mathrm{was} \mathrm{washed} \mathrm{with} \mathrm{water} \mathrm{until} \mathrm{the}$ effluent was free from hexane diamine [negative to the trinitrobenzene sulphonate test (Inman \& Dintzis, 1969)]. The column was then eluted with a 0 to $1 \mathrm{M}$ gradient of the ammonium carbonate buffer in a total volume of $500 \mathrm{ml}$ and the major UV-absorbing peak was collected. This was reduced by rotary evaporation to $20 \mathrm{ml}$ and precipitated by addition of 5 vol. ice-cold ethanol before being re-dissolved in $\mathrm{Na}_{2} \mathrm{CO}_{3} / \mathrm{NaHCO}_{3}$ buffer $(0.1 \mathrm{M}$, pH 9.5) and coupled to cyanogen bromide activated Sepharose 6B (Nishikawa \& Bailon, 1975).

Electrophoresis. Disc-gel electrophoresis was done by the method of Hayes \& Wellner (1969). Staining for protein was done by the method of Lumsden \& Coggins (1977).

\section{RESULTS}

\section{Enzyme activities under different growth conditions}

The activities of the various enzymes in crude extracts of bacteria grown in the presence of different carbon and nitrogen sources were measured (Table 1). No NADP ${ }^{+}$-dependent GDH was detectable in this strain of $B$. stearothermophilus and the activity of $\mathrm{NAD}^{+}$-dependent GDH did not vary significantly under the test conditions. Growth in the presence of L-glutamate did not cause any increase in the activity of $\mathrm{NAD}^{+}$-dependent GDH, suggesting that this enzyme does not serve to deaminate L-glutamate and that this amino acid is metabolized by transamination. 
Table 1. Enzyme activities in crude extracts of B. stearothermophilus PH24 grown in the presence of different carbon and nitrogen sources

\begin{abstract}
The concentration of all carbon sources was $2 \mathrm{~g} \mathrm{l}^{-1}$ except in the case of the 2-oxoglutarate/fumarate mixture where the ratio was $2: 1$. Activities are expressed as IU (mg protein $)^{-1}$. Glutamate dehydrogenase was only present in the $\mathrm{NAD}^{+}$-dependent form.
\end{abstract}

\begin{tabular}{lccccc}
\multicolumn{1}{c}{ Carbon source } & $\begin{array}{c}\mathrm{NH}_{4} \mathrm{Cl} \\
\left(\mathrm{g} \mathrm{l}^{-1}\right)\end{array}$ & GDH & AlaDH & GS & GOGAT \\
Fumarate & 0.8 & 0.05 & 0.43 & ND & 0.01 \\
Fumarate & 0.2 & 0.05 & 0.12 & 0.5 & 0.02 \\
2-Oxoglutarate & 0.8 & 0.06 & 0.93 & 0.6 & 0.02 \\
2-Oxoglutarate & 0.2 & 0.17 & 0.15 & 0.7 & 0.02 \\
2-Oxoglutarate/fumarate & 0.8 & 0.07 & 0.51 & 0.5 & 0.03 \\
Glutamate & 0 & 0.08 & 0.30 & 1.3 & ND \\
Alanine & 0 & 0.07 & 2.80 & ND & ND \\
& & & & &
\end{tabular}

ND, Not detected.

Activities of $\mathrm{AlaDH}$ were more variable. Growth with $\mathrm{L}$-alanine as both carbon and nitrogen source had the effect of inducing the enzyme, suggesting that it has a catabolic function as previously postulated in B. stearothermophilus (Epstein \& Grossowicz, 1976). However, cells grown in medium containing $\mathrm{NH}_{4} \mathrm{Cl}$ at $0.8 \mathrm{~g} \mathrm{l}^{-1}$ (high) as nitrogen source also had elevated AlaDH activity when compared to those grown with $\mathrm{NH}_{4} \mathrm{Cl}$ at $0.2 \mathrm{~g} \mathrm{l}^{-1}$ (low). It may be that, in the absence of $\mathrm{NADP}^{+}$-dependent $\mathrm{GDH}$, AlaDH is involved in ammonia assimilation at high levels of ammonia and that glutamate is formed by transamination from alanine.

Although GS activity was only assayed by the transferase assay, it was evident that high levels of ammonia caused a decrease in the cell content of this enzyme, especially when fumarate was used as carbon source. Higher activities were obtained from cells grown on low ammonia and fumarate indicating that this enzyme is assimilatory under these conditions.

The activity of GOGAT was not significantly affected by ammonia levels in the medium or the type of carbon source supplied. GOGAT was undetectable during growth in the presence of amino acids. The mesophile Bacillus megaterium behaves similarly, producing GOGAT under all conditions except where amino acids are supplied in the growth medium (Elmerich \& Aubert, 1971).

\title{
Purification and properties of glutamate synthase
}

Growth on a mixture of 2-oxoglutarate and fumarate in the presence of high $\mathrm{NH}_{4} \mathrm{Cl}$ produced slightly more GOGAT than other conditions (Table 1). For this reason, the organism was routinely grown on this medium to provide material for enzyme purification.

The crude cell extract from $8 \mathrm{~g}$ cells was fractionated using $\left(\mathrm{NH}_{4}\right)_{2} \mathrm{SO}_{4}$ and the fraction precipitating between 40 and $50 \%$ saturation of this salt contained all of the GOGAT activity. This precipitate was collected by centrifugation, re-suspended in the $\mathrm{pH} 6.0$ buffer and dialysed against the same buffer to remove the $\left(\mathrm{NH}_{4}\right)_{2} \mathrm{SO}_{4}$. The dialysed material was clarified by centrifugation and the supernatant was gel filtered through tandem columns (each $2.5 \times$ $70 \mathrm{~cm}$ ) of Sephacryl S-300 using the same buffer to elute. Active fractions, now containing only proteins in the 120000 to 200000 molecular weight range, were applied to a $1.5 \times 5 \mathrm{~cm}$ column of $2^{\prime}, 5^{\prime}$-ADP-Sepharose to remove unwanted NADP ${ }^{+}$-binding enzymes. The effluent from this first affinity column was applied directly to a $0.5 \times 5 \mathrm{~cm}$ column of NADPH-Sepharose to which the GOGAT was adsorbed. The NADPH-Sepharose was washed with pH 6.0 buffer until the effluent was free from protein before the GOGAT was eluted using a 0 to $1 \mathrm{~mm}$ gradient of NADPH in $50 \mathrm{ml}$ of the same buffer supplemented with 5 mM-L-glutamine and $5 \mathrm{~mm}$-2-oxoglutarate. The two substrates were included to protect the 
Table 2. Partial purification of GOGAT from B. stearothermophilus PH24

\begin{tabular}{lcccr}
\multicolumn{1}{c}{ Fraction } & $\begin{array}{c}\text { Total protein } \\
(\mathrm{mg})\end{array}$ & $\begin{array}{c}\text { Specific activity } \\
{[\mathrm{IU}(\mathrm{mg} \text { protein) }}\end{array}$ & $\begin{array}{c}\text { Purification } \\
\text { factor }\end{array}$ & $\begin{array}{c}\text { Yield } \\
(\%)\end{array}$ \\
$\begin{array}{l}\text { Crude extract } \\
\left.\text { (NH }_{4}\right)_{2} \mathrm{SO}_{4} \text { fraction }\end{array}$ & 276 & 0.028 & 1 & 100 \\
$\begin{array}{l}\text { Sephacryl S-300 gel } \\
\text { filtrate }\end{array}$ & 16.8 & 0.103 & 3.7 & 94 \\
$\begin{array}{l}\text { Eluate from } \\
\text { NADPH-Sepharose }\end{array}$ & 3.2 & 0.346 & 12.5 & 76 \\
\end{tabular}

GOGAT from damage by NADPH (see later); they were removed along with the NADPH by gel filtration through Sephadex G25.

The final preparation, as used for further studies, was estimated to be $10 \%$ pure by gel electrophoresis, there being three dark and several light bands in protein stains of disc gels. It was, however, purified 40 -fold (Table 2) and was free from NADPH oxidase, NAD ${ }^{+}$ dependent GDH and other enzymes likely to interfere with the GOGAT assay.

\section{Effect of $p H$ on glutamate synthase activity}

The optimum $\mathrm{pH}$ for GOGAT activity with L-glutamine as nitrogen donor was $8 \cdot 0$, with $50 \%$ of maximum activity being retained at $\mathrm{pH} 6.4$ and $\mathrm{pH} 9.0$.

\section{Co-factor and substrate specificities}

The enzyme required NADPH as co-factor and this could not be replaced by NADH; the apparent $K_{\mathrm{m}}$ for the dinucleotide was $22 \mu \mathrm{M}$ (determined by the method of Eisenthal \& Cornish-Bowden, 1974). The requirement for 2-oxoglutarate was also absolute $\left(K_{\mathrm{m}} 15 \mu \mathrm{M}\right)$ although both L-glutamine $\left(K_{\mathrm{m}} 29 \mu \mathrm{M}\right)$ and $\mathrm{NH}_{4} \mathrm{Cl}\left(K_{\mathrm{m}} 44 \mathrm{mM}\right)$ could act as nitrogen donor. With $100 \mathrm{~mm}-\mathrm{NH}_{4} \mathrm{Cl}$ replacing the L-glutamine, the rate of dinucleotide oxidation was only 10 to $15 \%$ the rate seen under normal assay conditions.

No activity in the reverse direction (i.e. glutamine-forming) could be detected.

The dinucleotide, in the absence of the other substrates, was a potent inactivator capable of causing $50 \%$ inactivation in $5 \mathrm{~min}$ when present at a concentration of $1 \mathrm{mM}$. This inactivation was previously reported as occurring in the Escherichia coli enzyme (Mäntsälä \& Zalkin, 1976) and was reduced by inclusion of 2-oxoglutarate or L-glutamine in the incubation mixture; inclusion of both substrates afforded complete protection.

\section{Enzyme inhibitors}

GOGAT from B. stearothermophilus PH24 was strongly inhibited by azaserine in both the L-glutamine- and $\mathrm{NH}_{4} \mathrm{Cl}$-dependent reactions. This observation confirms that the thermophilic enzyme resembles that from other sources (Miflin \& Lea, 1976) and that the activity is not due to an $\mathrm{NADP}^{+}$-dependent GDH.

The thermophilic enzyme was also strongly and competitively inhibited by L-methionine sulphone $\left(K_{\mathrm{i}} 22 \mu \mathrm{M}\right)$ and Cibacron Blue 3GA $\left(K_{\mathrm{i}} 12 \mu \mathrm{M}\right)$. However, no significant inhibition was caused by $2^{\prime}, 5^{\prime}$-ADP, an NADP ${ }^{+}$-analogue which competitively inhibits $E$. coli GOGAT $\left(K_{\mathrm{i}} 106 \mu \mathrm{M}\right.$; Schmidt \& Jervis, 1980). The reason for this difference in the effect of this dinucleotide analogue is unclear but it explains why the thermophilic enzyme failed to bind to an adsorbent based on this ligand, which was previously used in the successful purification of E. coli GOGAT (Schmidt \& Jervis, 1980).

\section{Effect of heat}

The temperature optimum was $75^{\circ} \mathrm{C}$ with $35 \%$ of the activity being lost during $10 \mathrm{~min}$ incubation at $80^{\circ} \mathrm{C}$. Over the temperature range $30^{\circ} \mathrm{C}$ to $75^{\circ} \mathrm{C}$ an Arrhenius plot shows a marked deviation from linearity, occurring at $58^{\circ} \mathrm{C}$ and giving two different activation 


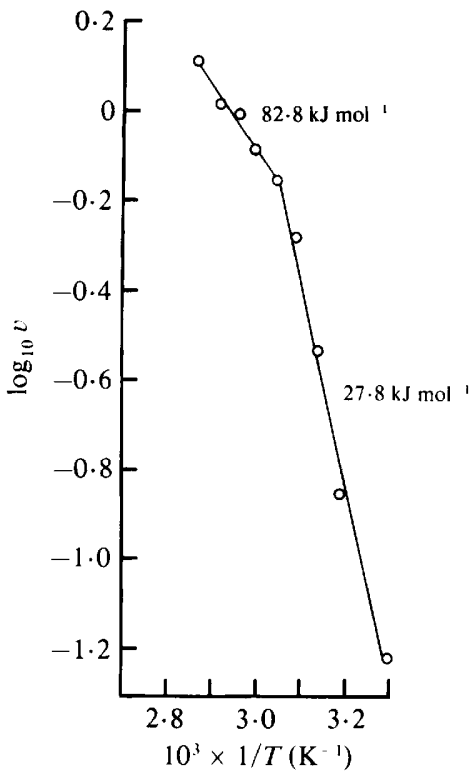

Fig. 1. Arrhenius plot for GOGAT from Bacillus stearothermophilus in the range $30^{\circ} \mathrm{C}$ to $75^{\circ} \mathrm{C}$.

energies (Fig. 1). Below $58^{\circ} \mathrm{C}$ the activation energy is $82.8 \mathrm{~kJ} \mathrm{~mol}^{-1}$ while above this temperature it falls to $27.8 \mathrm{~kJ} \mathrm{~mol}^{-1}$. The form of the plot and the temperature at which the discontinuity occurs is similar to that seen in GS from $B$. stearothermophilus (Wedler \& Hoffman, 1974).

\section{Molecular weight}

Using gel filtration (Andrews, 1965), the molecular weight was estimated at 160000 , a much lower value than that obtained for the enzymes from $E$. coli $(800000$; Miller \& Stadtman, 1972) or Bacillus megaterium (800000; Hemmilä \& Mäntsälä, 1978). However, it is similar to the estimated molecular weight of GOGAT from Bacillus subtilis (173000; Deshpande \& Kane, 1980).

\section{DISCUSSION}

From the results obtained, GOGAT appears to be important in ammonia assimilation in $B$. stearothermophilus PH24 just as it is in other bacteria under ammonia-limited conditions (Tempest et al., 1973). Its presence at such low levels, however (Table 1), prompted a search for some alternative amidotransferase capable of utilizing glutamine for amino acid formation, but none was found.

The fact that GS is repressed at high ammonia levels suggests that some alternative means of assimilation exists under these conditions. No anabolic GDH is present as in $K$. aerogenes (Tempest et al., 1970) but AlaDH activity is higher under these conditions and it is possible that this enzyme functions to assimilate ammonia despite previous reports that it is purely catabolic in this organism (Epstein \& Grossowicz, 1976).

The GOGAT from strain PH24 appears to be basically similar to that from mesophilic sources already studied. The major difference is that the temperature optimum is much higher and similar to that of other B. stearothermophilus enzymes (Amelunxen \& Murdock, 1978) and that the molecular weight is very low. Possibly the GOGAT enzymes from bacilli are of low molecular weight, since that from B. subtilis is only 173000 (Deshpande \& Kane, 1980) 
and that from B. megaterium was found as a 200000 dalton dimer (Hemmilä \& Mäntsälä, 1978).

Other properties, such as the inactivation by NADPH, suggest a similar catalytic centre to that in $E$. coli GOGAT, containing flavin, cysteine and non-haem iron: the inactivation caused by dinucleotide is dependent on the presence of these (Mäntsälä \& Zalkin, 1976).

In conclusion it should be noted that the GOGAT from strain PH24 was difficult to purify, a similar difficulty being reported by Wedler \& Hoffman (1974) with the GS from $B$. stearothermophilus. The affinity purification system developed for $E$. coli GOGAT and based on $2^{\prime}, 5^{\prime}$-ADP-Sepharose (Schmidt \& Jervis, 1980) was ineffective, and a new system was required. It is hoped that further refinements will result in higher purification factors being achieved.

L. Jervis wishes to thank the Royal Society for a Scientific Investigation Grant. C.N.G. Schmidt was in receipt of a Science Research Council Research Studentship.

\section{REFERENCES}

Amelunxen, R. E. \& Murdock, A. L. (1978). In Microbial Life in Extreme Environments, pp. 217-278. Edited by D. J. Kushner. London: Academic Press.

ANDREWs, P. (1965). The gel-filtration behaviour of proteins related to their molecular weights over a wide range. Biochemical Journal 96, 595-606.

BarnetT, J. A. \& INGRAM, M. (1955). Techniques in the study of yeast assimilation reactions. Journal of Applied Bacteriology 18, 131-143.

Buswell, J. A. \& TwOMEy, D. G. (1975). Utilization of phenol and cresols by Bacillus stearothermophilus strain PH24. Journal of General Microbiology 87, 377-379.

Deshpande, K. L. \& Kane, J. F. (1980). Glutamate synthase from Bacillus subtilis: in vitro reconstitution of an active amido-transferase. Biochemical and Biophysical Research Communications 93, 308-314.

Eisenthal, R. \& CoRnish-Bowden, A. (1974). The direct linear plot. A new graphical procedure for estimating enzyme kinetic parameters. Biochemical Journal 139, 715-720.

Elmerich, C. \& Aubert, J.-P. (1971). Synthesis of glutamate by a glutamine: 2 oxogluterate amidotransferase (NADP-oxidoreductase) in Bacillus megaterium. Biochemical and Biophysical Research Communications 42, 371-376.

EpsteIN, I. \& Grossowicz, N. (1975). Purification and properties of glutamate dehydrogenase from a thermophilic bacillus. Journal of Bacteriology 122 , 1257-1264.

EpsteiN, I. \& Grossowicz, N. (1976). Regulatory control and function of alanine dehydrogenase from a thermophilic bacillus. Biochimica et biophysica acta 445, 549-557.

Hayes, M. B. \& Wellner, D. (1969). Microheterogeneity of L-amino acid oxidase. Journal of Biological Chemistry 244, 6636-6644.

Hemmilä, I. A. \& MÄNtsäLÄ, P. I. (1978). Purification and properties of glutamate synthase and glutamate dehydrogenase from Bacillus megaterium. Biochemical Journal 173, 45-52.

Hong, M. M., Shen, S. C. \& Braunstein, A. G. (1959). Distribution of L-alanine dehydrogenase and L-glutamate dehydrogenase in baculi. Biochimica et biophysica acta 36, 288-289.
InMaN, J. K. \& DinTzIs, H. M. (1969). The derivatization of cross-linked polyacrylamide beads. Controlled introduction of functional groups for the preparation of special purpose, biochemical adsorbents. Biochemistry 8, 4074-4082.

Lumsden, J. \& CogGINS, J. R. (1977). The subunit structure of the arom multienzyme complex of Neurospora crassa. Biochemical Journal 161, 599607.

MÄNTSÄLÄ, P. \& ZALKIN, H. (1976). Glutamate synthase: properties of the glutamine-dependent activity. Journal of Biological Chemistry 251, 3294-3299.

Miflin, B. J. \& LEA, P. J. (1976). The pathway of nitrogen assimilation in plants. Phytochemistry 15, 873-885.

Miller, R. E. \& Stadtman, E. R. (1972). Glutamate synthase from Escherichia coli. Journal of Biological Chemistry 247, 7407-7419.

Nagatani, H., Shimizu, M. \& Valentine, R. C. (1971). The mechanism of ammonia assimilation in nitrogen fixing bacteria. Archiv für Mikrobiologie 79, 164-175.

Nishikawa, A. H. \& BaIlon, P. (1975). Affinity purification methods. Improved procedure for cyanogen bromide reaction on agarose. Analytical Biochemistry 64, 268-275.

Schmidt, C. N. G. \& Jervis, L. (1980). Affinity purification of glutamate synthase from Escherichia coli. Analytical Biochemistry 104, 127-129.

Tempest, D. W., Meers, J. L. \& Brown, C. M. (1970). Synthesis of glutamate in Aerobacter aerogenes by a hitherto unknown route. Biochemical Journal 117, 405-407.

Tempest, D. W., MeERs, J. L. \& Brown, C. M. (1973). Glutamate synthase (GOGAT); a key enzyme in the assimilation of ammonia by prokaryotic organisms. In The Enzymes of Glutamine Metabolism, pp. 167-182. Edited by S. Prusiner \& E. R. Stadtman. New York: Academic Press.

WEDLER, F. C. \& HofFMAN, F. M. (1974). Glutamine synthetase of Bacillus stearothermophilus. I. Purification and basic properties. Biochemistry 13, 3207-3214. 